\title{
Antibiotics Resistance of Bacteria Associated with Pneumonia in HIV/AIDS Patients in Nigeria
}

\author{
Ojo- Bola. $\mathrm{O}^{1, *}$, Oluyege A.O ${ }^{2}$ \\ ${ }^{1}$ Medical Microbiology Departments, Federal Medical Centre, Ido-Ekiti, Ekiti State, Nigeria \\ ${ }^{2}$ Department of Microbiology, Ekiti State University, Ado -Ekiti, Ekiti State, Nigeria \\ *Corresponding author: ojobolaoluwatosin01@gmail.com
}

Received October 27, 2014; Revised November 17, 2014; Accepted November 20, 2014

\begin{abstract}
This study was conducted to determine the antimicrobial resistance of bacteria associated with pneumonia in HIV/AIDS and HIV negative patients attending Federal Medical Centre, Ido-Ekiti, Ekiti State. A total of 300 sputum samples were collected (180 from HIV/AIDS patients and 120 samples from HIV negative patients diagnosed for pneumonia) and were selected by random sampling. The sputum samples were collected and examined for bacteria using microscopic, cultural and biochemical characteristics. Antibiogram was carried out by disc diffusion method. Results showed that male subjects with HIV/AIDS were more susceptible to infection by bacteria associated with pneumonia than females. The age group of 31-40 years and 71-80 years had the highest occurrence of bacterial pneumonia in HIV/AIDS and HIV negative populations respectively. The prevalence of pneumonia in HIV/AIDS and HIV negative patients was $55.6 \%$ and $43.3 \%$ respectively. A variety of bacteria was isolated in both populations with Escherichia coli (40\%) predominating in HIV/AIDS patients followed by Pseudomonas aeruginosa (35\%), S. aureus (20\%) and the least was Klebsiella pneumoniae (5\%). K. pneumoniae (44.2\%) was the predominant bacterium in HIV-negative patients, followed by Streptococcus pneumoniae (30.8\%) and S. aureus (25.0\%) These bacterial isolates were tested for resistance to twenty antibiotics prescribed in hospitals. However, resistance to antibiotics ranged between $52.5 \%$ to $100 \%$ in HIV/AIDS patients and $18.8 \%$ to $84.6 \%$ in HIV negative patients. Multiple antibiotic resistance to nine classes of these twenty antibiotics was observed in $53.0 \%$ and $19.2 \%$ of all organisms isolated from HIV/AIDS group and HIV negative patients respectively. However, the variation in the profile of bacterial organism isolated in both populations was statistically significant; suggesting that immune status of HIV/AIDS patients predisposed them to infection by some of the bacteria.
\end{abstract}

Keywords: antibiotics, bacteria, HIV/AIDS, pneumonia, Nigeria

Cite This Article: Ojo- Bola. O, and Oluyege A.O, "Antibiotics Resistance of Bacteria Associated with Pneumonia in HIV/AIDS Patients in Nigeria." American Journal of Infectious Diseases and Microbiology, vol. 2, no. 6 (2014): 138-144. doi: 10.12691/ajidm-2-6-1.

\section{Introduction}

It is well known that patients with HIV have an increased risk of respiratory tract infections. Even modest immune damage can leave individuals vulnerable to bacterial infections [1]. Bacterial infections are a major cause of morbidity and mortality in HIV-infected children and adult. The spectrum of disease is wide, and responsible organisms vary according to setting [2].

However, since the beginning of the AIDS epidemic, the lungs have continued to be a frequent site of organ complication. Traditionally, pulmonary infections in patients with HIV have been classified into opportunistic and non opportunistic. Opportunistic infections are caused by organisms that do not cause disease in immunocompetent individuals [3]. Respiratory disease is highly prevalent in HIV-infected subjects and $S$. pneumoniae and $M$. tuberculosis are the leading causes. Similarly, data presented at a 2003 World Health Organization (WHO) conference indicated that pneumonia in HIV-infected children was the leading cause of hospital admission and most frequent cause of death in the six participating African countries [4].

Pneumonia in the immunocompromised host involves infection and inflammation of the lower respiratory tract. Regardless of the reason for altered immune function, pneumonia carries a high mortality rate in immunocompromised patients [5]. Pneumonia is common, occurring in all age groups, and is a leading cause of death among the young, the old, and the chronically ill [6]. Over two million children under five die each year worldwide and it is estimated that up to 1 million of these deaths are caused by the bacteria S. pneumoniae, and over $90 \%$ of these deaths take place in developing countries.

The incidence of bacterial pneumonia in HIV-infected patients ranges from 1.93 to $19.2 \%$ cases per 100 patients per year. Since the introduction in 1996 of highly active antiretroviral therapy, a reduction in the opportunistic disease, including recurent bacteria Pneumonia has occurred, nevertheless, bacterial pneumonia continues to be an important problem in HIV infected patient [7]. 
However, the problem of antibiotic resistance in bacterial pathogens increases the growing concern among health care worker on the continued ineffectiveness of antibiotics in the emperical management of HIV/AIDS patients. Bacteria-related pulmonary infection is a common respiratory complication. This has posed a major threat to the management of HIV infected patients. Nevertheless, antibiotic therapy is fundamental to illness control in this group of patients because of their impaired immunity. Unfortunately, the incidence of bacterial resistance to antibiotics is high and therefore posing a major challenge to the treatment / management of these patients. It becomes imperative therfore to identify the type(s) of bacterial pnemonia, the resistance of causative organisms to antibiotics. This will provide a more recent update on the use of appropriate and more effective treatment regimens.

\section{Methodology}

\subsection{Study Location}

The study location for this work was Federal Medical Centre, Ido-Ekiti located in Ekiti North Senatorial district of Ekiti State, Nigeria.

\subsection{Study Population}

The study populations were HIV/AIDS patients and HIV negative patients as control populations attending the above-named Hospital.

\subsection{Ethical Consideration, Questionnaire and Informed Consent}

The ethical clearance for this research was given by Federal Medical Centre (FMC) ethical committee after due processes had been followed. Questionnaire to obtain the demographic characteristics and other relevant information to the study as well as an informed consent were administered to the participant.

\subsection{Screening of HIV}

The determine HIV-1/2 (manufactured by Abbot Diagnostic, USA) was used in conjunction with STATPAK (manufactured by Chembio Diagnostic, New York) which are in vitro, visually ready, qualitative immunoassays for the detection antibodies to HIV-1 and HIV-2 in human plasma.

\subsection{Sample Collection}

Sterile universal bottles were given to the patient and adequately instructed on the type of sample to be collected and that aseptic condition was required.

\subsection{Sample Processing}

The sputum sample was examined macroscopically with naked eyes and stained with Gram's Method as described by [8].

A loopful of saliva free sputum was inoculated unto Chocolate agar and MacConkey agar plates both incubated anaerobically and aerobically respectively at $37^{\circ} \mathrm{C}$ for 24 hours. To ensure minimal saliva contamination, patient was instructed to pre-rinse their mouth prior to the collection. For children, a cough plate was held before the child's mouth as he/she coughed after pre-rinsing the mouth with sterile water [4].

\subsection{Biochemical Tests}

Catalase test, Coagulase test for Staphylococcus species while Optochin test, Bile solubility test, Bacitracin test for Streptococcus species; Substrate fermentation test, Motility, Citrate, Oxidase test, Urease and Indole test were used for tentative identification of Gram negative bacilli [9].

\subsection{Serological Test}

Serological test was carried out using polyvalent antisera specific for each organism for their identification according to the manufacturer's instructions (Oxoid diagnostic kit manual).

\subsection{Sources of Antibiotics}

Twenty antibiotics of nine different classes were tested. The antibiotics, their codes and concentration (in $\mu g$ except penicillin in units) were as follow: Aminoglycosides: Streptomycin (STR) (10), Gentamycin (GM) (10). ß-Lactam: Augumentin (AUG) (30). Cephems: Cefixime (MXP) (30), Ceftazidime (CAZ) (30), Cefepime (CPM) (30), Ceftriaxone (CRO) (30), Cefuroxime (CXM) (25). Fluroquinolones: Ciprofloxacin (CPX) (10), Sparfloxacin (SPX) (5), Perfloxacin (PFX) (5), Levofloxacin (LEV) (5). Folate pathway inhibitor: Cotrimoxazole (COT) (25). Penicillin: PenicillinG (PG) (10), Amoxicillin (AMX) (25). Macrolide: Clarithromycin (CLA) (15), Erythromycin (ERY) (15), Azithromycin (ATH) (15). Phenicols: Chloramphenicol (CHL) (30). Teteracyclines: Tetracycline (TET) (30).

\subsection{Antibiotics Susceptibility Testing}

Antibiotics susceptibility testing was performed according to standard procedures by CLSI (2010) (Disc agar diffusion method).

\subsection{Statistical Analysis}

The data generated from this study were analysis using SPSS version 16 (SPSS Inc. Chigago IL).

\section{Results}

The prevalence of pneumonia in HIV/AIDS and HIVnegative patients showed that out of 180 HIV/AIDS patients that participated, bacteria associated with pneumonia were isolated from 100 (55.6\%) patients while out of 120 HIV-negative patients; bacteria associated with pneumoniae were 52 (43.3\%). The bacteria associated with pneumonia from HIV/AIDS and HIV negative patients in relation to gender are shown in Table 1 . It shows that four different genera of bacteria were identified. Forty strains $(40.0 \%)$ of $E$. coli were isolated with the higher occurrence in male subjects (72.5\%). Thirty- five (35.0\%) $P$. aeruginosa were isolated with the higher 
occurrence in female subjects (54.3\%). Twenty (20.0\%) and $5(5.0 \%) S$. aureus and $K$. pneumoniae respectively were also isolated with higher occurrence in male subjects. The bacteria associated with pneumonia in HIV/AIDS in relation to sex is statistically significant with $\mathrm{P}$ value $0.035\left(\mathrm{df}=3, \mathrm{X}^{2}=8.591\right)$. However, three different genera of bacteria were isolated among HIV negative patients.
Out of 52 bacteria isolated, $K$. pneumoniae was the highest organism isolated (44.2\%), followed by $S$. pneumoniae (30.8\%) and S. aureus (25.0\%). Female subjects are more infected with bacteria-associated pneumonia than male subjects. This was not statistically significant because the $\mathrm{P}$ value is greater than $0.05(\mathrm{P}$ value $\left.=0.787, \mathrm{df}=2, \mathrm{X}^{2}=0.478\right)$.

Table 1. Bacteria Associated with pneumonia in HIV/AIDS and HIV negative patients in relation to gender

\begin{tabular}{|c|c|c|}
\hline \multicolumn{2}{|l|}{ Bacteria } & Total no (\%) \\
\hline \multicolumn{3}{|c|}{ HIV/AIDS PATIENTS $(\mathrm{n}=100)$} \\
\hline \multicolumn{2}{|l|}{ Escherichia coli } & $40(40.0)$ \\
\hline \multicolumn{2}{|c|}{ Pseudomonas aeruginosa } & $35(35.0)$ \\
\hline \multicolumn{2}{|l|}{ Staphylococcus aureus } & $20(20.0)$ \\
\hline \multicolumn{2}{|l|}{ Klebsiella pneumonia } & $5(5.0)$ \\
\hline \multicolumn{3}{|c|}{ HIV NEGATIVE PATIENTS $(n=52)$} \\
\hline \multicolumn{2}{|c|}{ Klebsiella pneumonia } & $23(44.2)$ \\
\hline \multicolumn{2}{|l|}{ Staphylococcus aureus } & $13(25.0)$ \\
\hline \multicolumn{2}{|c|}{ Streptococcus pneumoniae } & $16(30.8)$ \\
\hline \multicolumn{3}{|c|}{$\begin{array}{l}\text { Table } 2 \text {. Age distribution of HIV/AIDS and HIV negative patients } \\
\text { with bacteria associated pneumonia }\end{array}$} \\
\hline Age group (in year) & HIV/AIDS patients & HIV negative patients \\
\hline $1-10$ & 2 & 1 \\
\hline $11-20$ & 11 & 3 \\
\hline $21-30$ & 9 & 9 \\
\hline $31-40$ & 62 & 2 \\
\hline $41-50$ & 13 & 6 \\
\hline $51-60$ & 1 & 3 \\
\hline $61-70$ & 0 & 2 \\
\hline $71-80$ & 1 & 21 \\
\hline 81-above & 1 & 5 \\
\hline Total & $100(55.6)$ & $52(43.3)$ \\
\hline
\end{tabular}

The age distribution of HIV/AIDS and HIV negative patients with bacteria associated pneumonia is shown in Table 2. Age group 31-40yrs had the highest infection for the entire organism isolated (62.0\%), followed by age group 41-50 (13.0\%), 11-20 (11.0\%) and 21-30 (9.0\%). No bacteria were isolated within the age group 61-70yrs. Gender

\begin{tabular}{|c|}
\hline $\mathrm{Ma}$ \\
\hline
\end{tabular}

\begin{tabular}{lllll}
$29(72.5)$ & $11(27.5)$ & & & \\
$16(45.7)$ & $19(54.3)$ & 0.035 & 3 & 8.591 \\
$16(80.0)$ & $4(20.0)$ & & & \\
$3(60.0)$ & $2(40.0)$ & & & \\
& & & & \\
$09(39.1)$ & $14(60.9)$ & & & \\
$06(46.2)$ & $07(53.8)$ & 0.787 & 2 & 0.478 \\
$08(50.0)$ & $08(50.0)$ & & & \\
\hline
\end{tabular}

Ages 51-60, 71-80 and 81-above had 1.0\% each in HIV/AIDS patients while age group 71-80 years had the highest infection $(21.0 \%)$ in HIV negative patients. The statistically analysis showed that the relationship between the age group and the type of bacteria in HIV/AIDS patients is statistically significant with $\mathrm{P}$ value less than 0.05 ( $P$ value $=0.00, \mathrm{df}=21, \mathrm{X}^{2=} 67.49$ ).

The percentage resistance of bacteria to antibiotics among HIV/AIDS and HIV-negative patients are presented in Figure 1 and Figure 2. It shows the antibiotics profile of the isolates to the 20 antibiotics prescribed in the hospital. $P$. aeruginosa isolates were $100 \%$ resistant to all the antibiotics except $94.3 \%$ and $97 \%$ resistant to sparfloxacin and ceftazidime respectively (Figure 1). All isolates except $P$. aeruginosa showed least resistant to sparfloxacin and ceftazidime. Even cotrimoxazole, a WHO recommended antibiotics for treatment of pneumonia showed a high rate resistance in HIV/AIDS and HIV-negative patients.

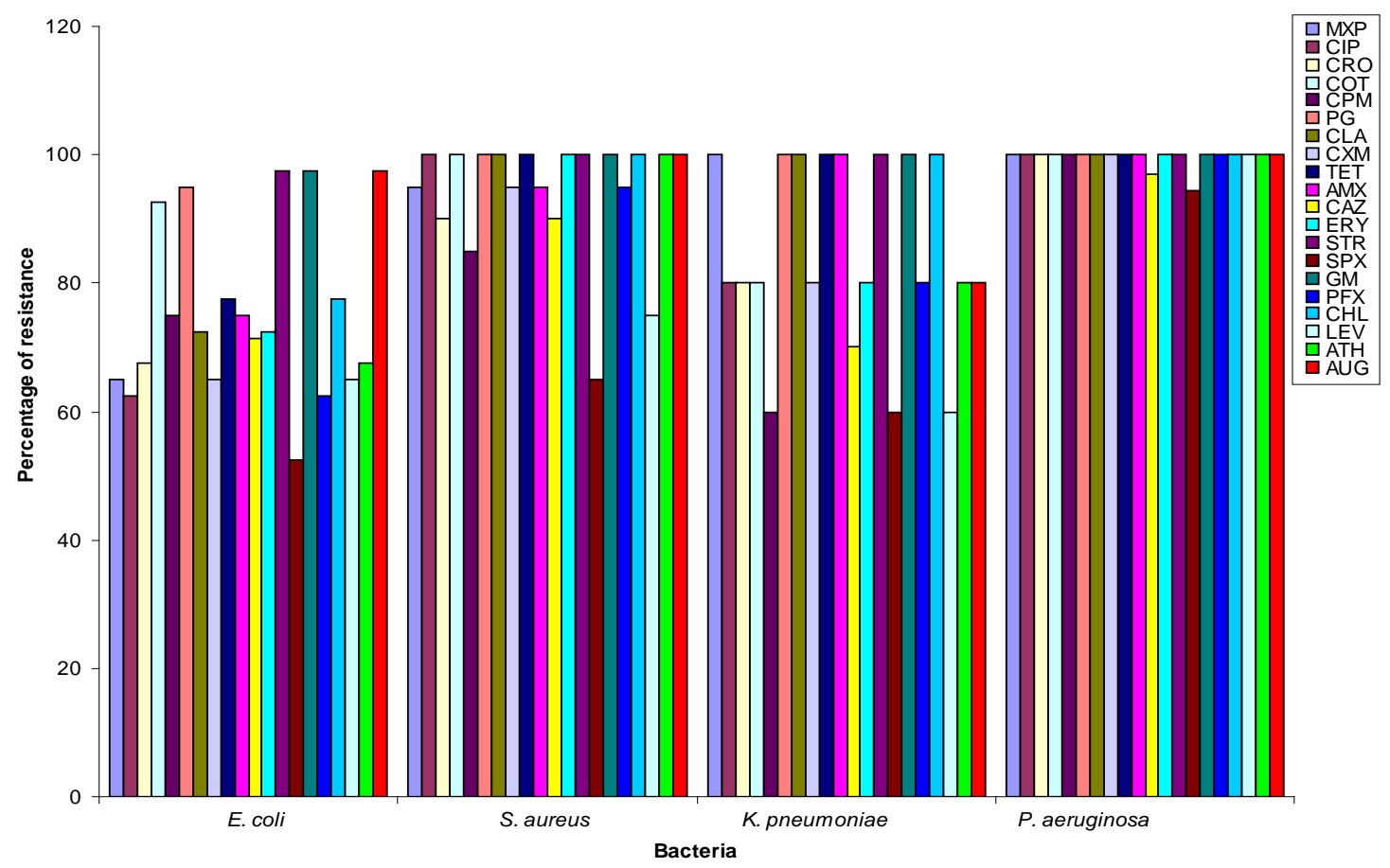

Figure 1. PERCENTAGE RESISTANCE OF BACTERIA TO ANTIBIOTICS AMONG HIV/AIDS PATIENTS 


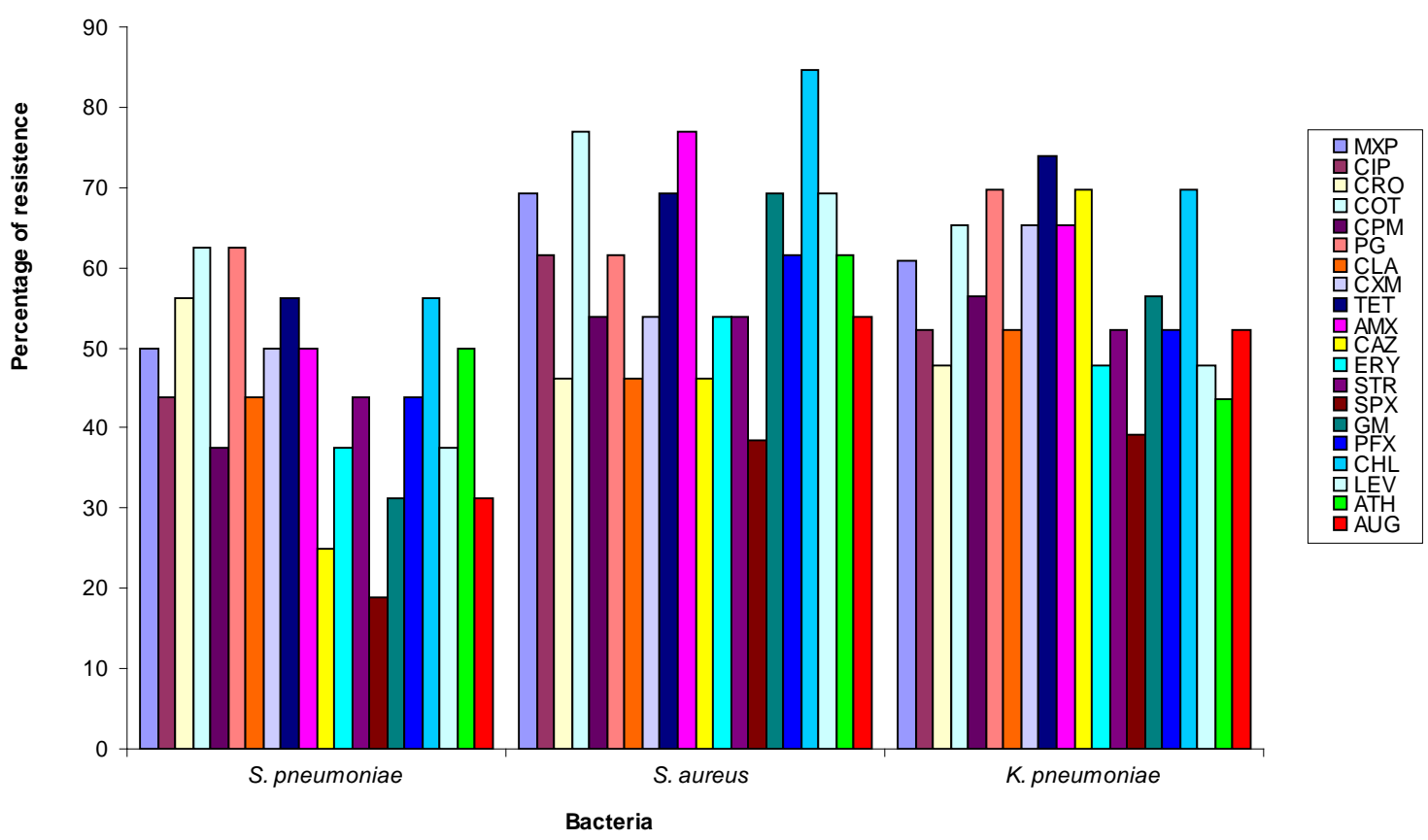

Figure 2. PERCENTAGE RESISTANCE OF BACTERIA TO ANTIBIOTICS AMONG HIV-NEGATIVE PATIENT

Multiple resistance to nine classes of antibiotics among HIV/AIDS and HIV negative patients are shown in Table 3. Fifty-three (53\%) of all the four bacterial species isolated from HIV/AIDS patients exhibited varying degrees of resistance to all the 9 classes of antibiotics tested. Out of which, 33(94.3\%) were $P$. aeruginosa, $11(27.5 \%)$ were $E$. coli, 7 (35.0\%) were S. aureus and 2 (40.0\%) were $K$. pneumoniae. Seven (17.5\%) E. coli, 8 (40.0\%) S. aureus and $1(20.0 \%) K$. pneumoniae showed resistance to 8 different classes of antibiotics. Six (15.0\%), 3 (15.0\%) and 2 (5.7\%) of E. coli, S. aureus, P. aeruginosa respectively showed resistance to 7 different classes of antibiotics. Four (10.0\%), 2 (10.0\%) and 1 (20.0\%) of E. coli, S. aureus and $K$. pneumoniae respectively showed resistance to 6 different classes of antibiotics. Eight (20.0\%) E. coli and $1(20.0 \%) K$. pneumoniae showed resistance to 5 different classes of antibiotics. Two (5.0\%) of E. coli showed resistance to 4 classes and 3 classes of antibiotics. However, among HIV negative patients, 10 (19.2\%) of all the bacterial isolates exhibited varying percentage of resistances to 9 different classes of antibiotics tested in this study. Out of which, 6 (26.0\%) were K. pneumoniae, 2 (15.4\%) were $S$. aureus and 2 (12.5\%) were $S$. pneumoniae. Four (17.4\%) K. pneumoniae, 4 (30.8\%) S. aureus and 1 (6.3\%) S. pneumoniae exhibited resistance to 8 different classes of antibiotics. Three (13.0\%), 5 (38.5\%) and $2(12.5 \%)$ of $K$. pneumoniae, S. aureus and $S$. pneumoniae respectively exhibited resistance to 7 classes of antibiotics. Three (13.0\%) and 5 (31.3\%) of $K$. pneumoniae and $S$. pneumoniae respectively showed resistance to 6 classes of antibiotics. One (4.4\%), 2(15.4\%) and 4 (25.0\%) of $K$. pneumoniae, S. aureus and $S$. pneumoniae respectively exhibited multiple resistance to 5 classes of antibiotics. Four (17.4\%) and 1 (6.3\%) of $K$. pneumoniae and $S$. pneumoniae respectively exhibited resistance to 4 classes of antibiotics. Two (8.7\%) $K$. pneumoniae and 1 (6.3\%) S. pneumonia exhibited multiple resistances to 3 classes of antibiotics.

Table 3. Multiple resistance to nine classes of antibiotics among HIV/AIDS and HIV negative patients

\begin{tabular}{|c|c|c|c|c|c|c|c|}
\hline \multirow{2}{*}{$\begin{array}{l}\text { Bacteria } \\
\text { HIV/AIDS } \\
\text { PATIENTS }\end{array}$} & \multicolumn{7}{|c|}{ No of classes of antibiotics to which multiple resistance were shown } \\
\hline & 9 classes & 8 classes & 7 classes & 6 classes & 5 classes & 4 classes & 3 classes \\
\hline $\begin{array}{l}\text { E. coli }(\mathrm{n}=40) \\
(\%)\end{array}$ & $\begin{array}{l}11 \\
(27.5)\end{array}$ & $\begin{array}{l}7 \\
(17.5)\end{array}$ & $\begin{array}{l}6 \\
(15.0)\end{array}$ & $\begin{array}{l}4 \\
(10.0)\end{array}$ & $\begin{array}{l}8 \\
(0.0)\end{array}$ & $\begin{array}{l}2 \\
(5.0)\end{array}$ & $\begin{array}{l}2 \\
(5.0)\end{array}$ \\
\hline $\begin{array}{l}\text { S. aureus }(\mathrm{n}=20) \\
(\%)\end{array}$ & $\begin{array}{l}7 \\
(35.0)\end{array}$ & $\begin{array}{l}8 \\
(40.0)\end{array}$ & $\begin{array}{l}3 \\
(15.0)\end{array}$ & $\begin{array}{l}2 \\
(10.0)\end{array}$ & $\begin{array}{l}0 \\
(0.0)\end{array}$ & $\begin{array}{l}0 \\
(0.0)\end{array}$ & $\begin{array}{l}0 \\
(0.0)\end{array}$ \\
\hline $\begin{array}{l}\text { P. aeruginosa }(\mathrm{n}=35) \\
(\%)\end{array}$ & $\begin{array}{l}33 \\
(94.3) \\
\end{array}$ & $\begin{array}{l}0 \\
(0.0) \\
\end{array}$ & $\begin{array}{l}2 \\
(5.7 \%)\end{array}$ & $\begin{array}{l}0 \\
(0.0) \\
\end{array}$ & $\begin{array}{l}0 \\
(0.0) \\
\end{array}$ & $\begin{array}{l}0 \\
(0.0)\end{array}$ & $\begin{array}{l}0 \\
(0.0)\end{array}$ \\
\hline $\begin{array}{l}\text { K. pneumoniae }(\mathrm{n}=5) \\
(\%)\end{array}$ & $\begin{array}{l}2 \\
(40.0)\end{array}$ & $\begin{array}{l}1 \\
(20.0)\end{array}$ & $\begin{array}{l}0 \\
(0.0)\end{array}$ & $\begin{array}{l}1 \\
(20.0)\end{array}$ & $\begin{array}{l}1 \\
(20.0)\end{array}$ & $\begin{array}{l}0 \\
(0.0)\end{array}$ & $\begin{array}{l}0 \\
(0.0)\end{array}$ \\
\hline $\begin{array}{l}\text { Total }(\mathrm{n}=100) \\
(\%)\end{array}$ & $\begin{array}{l}53 \\
(53.0)\end{array}$ & $\begin{array}{l}16 \\
(16.0)\end{array}$ & $\begin{array}{l}11 \\
(11.0)\end{array}$ & $\begin{array}{l}7 \\
(7.0)\end{array}$ & $\begin{array}{l}9 \\
(9.0)\end{array}$ & $\begin{array}{l}2 \\
(2.0)\end{array}$ & $\begin{array}{l}2 \\
(2.0)\end{array}$ \\
\hline \multicolumn{8}{|l|}{$\begin{array}{l}\text { HIV NEGATIVE } \\
\text { PATIENTS }\end{array}$} \\
\hline $\begin{array}{l}\text { K. pneumoniae }(\mathrm{n}=23) \\
(\%)\end{array}$ & $\begin{array}{l}6 \\
(26.0)\end{array}$ & $\begin{array}{l}4 \\
(17.4)\end{array}$ & $\begin{array}{l}3 \\
(13.0)\end{array}$ & $\begin{array}{l}3 \\
(13.0)\end{array}$ & $\begin{array}{l}1 \\
(4.4)\end{array}$ & $\begin{array}{l}4 \\
(17.4)\end{array}$ & $\begin{array}{l}2 \\
(8.7)\end{array}$ \\
\hline $\begin{array}{l}\text { S. aureus }(\mathrm{n}=13) \\
(\%)\end{array}$ & $\begin{array}{l}2 \\
(15.4)\end{array}$ & $\begin{array}{l}4 \\
(30.8)\end{array}$ & $\begin{array}{l}5 \\
(38.5) \\
\end{array}$ & $\begin{array}{l}0 \\
(0.0) \\
\end{array}$ & $\begin{array}{l}2 \\
(15.4)\end{array}$ & $\begin{array}{l}0 \\
(0.0) \\
\end{array}$ & $\begin{array}{l}0 \\
(0.0)\end{array}$ \\
\hline $\begin{array}{l}\text { S. pneumoniae }(\mathrm{n}=16) \\
(\%)\end{array}$ & $\begin{array}{l}2 \\
(12.5)\end{array}$ & $\begin{array}{l}1 \\
(6.3)\end{array}$ & $\begin{array}{l}2 \\
(12.5)\end{array}$ & $\begin{array}{l}5 \\
(31.3)\end{array}$ & $\begin{array}{l}4 \\
(25.0)\end{array}$ & $\begin{array}{l}1 \\
(6.3)\end{array}$ & $\begin{array}{l}1 \\
(6.3)\end{array}$ \\
\hline $\begin{array}{l}\text { Total }(\mathrm{n}=52) \\
(\%)\end{array}$ & $\begin{array}{l}10 \\
(19.2)\end{array}$ & $\begin{array}{l}9 \\
9\end{array}$ & $\begin{array}{l}10 \\
(19.2)\end{array}$ & $\begin{array}{l}8 \\
(15.4)\end{array}$ & $\begin{array}{l}7 \\
(13.5)\end{array}$ & $\begin{array}{l}5 \\
(9.6)\end{array}$ & $\begin{array}{l}3 \\
(5.8)\end{array}$ \\
\hline
\end{tabular}




\section{Discussion}

Pneumonia is a common illness in all parts of the world. It is a major cause of death among all age groups and a leading cause of death in children in low income countries [9]. Data presented at a 2003 WHO conference indicated that pneumonia in HIV-infected children was the leading cause of hospital admission and most frequent cause of death in the six participating African countries [4]. Bacterial pneumonia also constitutes a major cause of death in HIV-infected patient with mortality in hospital or after 4 weeks [6].

In this study, there was a statistically significant difference in the prevalence of bacteria associated with pneumoniae among HIV/AIDS and HIV-negative patients ( $P$ value 0.038 ). This is because debilitated immune system can leave individual vulnerable to bacteria infection and this agreed with work of [1] that said modest immune damage can expose individual to bacterial infection most especially in advanced HIV disease. This is equally supported by [11] who reported that HIV positive individuals are immunocompromised and are thus more susceptible to even low grade pathogens than HIVnegative individuals. This study also confirms that both Gram positive and Gram negative organism can cause pneumonia. This also agreed with the work of Anevlavis and Bouros (2010) that reported S. aureus as one of the Gram positive organisms that cause pneumonia, and $H$. influenzae, K. pneumoniae, E. coli, P. aeruginosa and $M$. catarrhalis as Gram-negative bacteria that cause pneumonia.

The mechanism of Gram positive and Gram negative bacteria in causing pulmonary pneumonia had been reported by Gadkowski and Stout (2008). It was said to involve two mechanisms. Organisms may enter the respiratory cavity via the oropharynx/upper airway, bypass host defenses, and cause either a necrotizing pneumonia or lung abscess; alternatively, organisms may enter the lung via the bloodstream, often in association with fibrin and platelets as septic pulmonary emboli. Anevlavis and Bouros (2010) revealed that bacteria typically enter the lung when airborne droplets are inhaled, but can also reach the lung through the bloodstream when there is an infection in another part of the body. Many bacteria live in parts of the upper respiratory tract, such as the nose, mouth and sinuses, and can easily be inhaled into the alveoli. Once inside, bacteria may invade the spaces between cells and between alveoli through connecting pores. This invasion triggers the immune system to send neutrophils to the lungs.

This study shows that there is variation in the occurrence of some of bacteria in both HIV/AIDS and HIV-negative patients. Both S. aureus and K. pneumoniae were common bacteria isolated in both study populations. This is supported by Gadkowski and Stout (2008) who reported $K$. pneumoniae and community-acquired methicillin resistant $S$. aureus, which usually possesses the Panton-Valentine leukocidin virulence factor as emerging cause of severe Community-acquired Pneumonia (CAP). This also agreed with work of Idris and Nasidi (2009) that reported S. aureus and K. Pneumoniae and other opportunistic organisms as cause of respiratory disease in a prolonged HIV infection. Meanwhile, the variation in general of some of the bacteria isolated in both studied population might be due to the fact that some bacteria like $P$. aeruginosa isolated in HIV/AIDS patients could be self-limiting most especially in immunocompetent patient. This agreed with previous work of Bekele and Bethany (2009) that revealed the defects in granulocyte, chemotaxis, phagocytosis and bacterial killing in HIVinfected patients and have predisposed them to $P$. aeruginosa infection. However, the rate of infection of $P$. aeruginosa in HIV/AIDS patient in this study is very high (35\%) and this supported Adeleye (2010) that said $P$. aeruginosa incidence in AIDS patients appears to be on the rise, with many studies demonstrating an annual increase in cases. Also Franzetti et al. (2007) reported $S$. aureus and $P$. aeruginosa as the leading causes of Nosocomial Bacteria Pneumonia (NBP). Falco et al. (1994) reported granulocytopenia as a predisposing factor to $P$. aeruginosa infection. Nevertheless, $P$. aeruginosa isolated in the study reported by Franzetti et al. (1992), showed that none had granulocytopenia, suggesting that the occurrence of $P$. aeruginosa pneumonia should certainly be regarded as an indicator of progression of immunodeficiency.

The occurrence of E. coli in HIV/AIDS patients might be due to the fact that the immune system of the patients had been compromised, giving room for an opportunistic bacterium. This is also supported by Vray et al. (2008) that more advanced HIV disease can expose individual to any bacterial infection. However, no E. coli was isolated from sputum of HIV-negative patients. It agreed with work of Okesola and Oni (2009) where no E. coli was isolated, nevertheless, occurrence of E. coli in HIV/AIDS patients in this present study was $40 \%$. This corresponds with report from other countries such as China, [22] where E. coli was reported to have been isolated in the sputum. The presence of $\mathrm{E}$. coli in lower respiratory tract could be as a result of micro aspiration of upper air ways secretions that have been previously colonized with this organism in severely ill patients; hence it is a cause of nosocomial pneumonia. E. coli pneumonia can also be communityacquired in patients who have underlying diseases (eMedicine.com). Microorganisms can also get to the lungs from foods contaminated with bacteria such as Escherichia coli which these immunocompromised patients eat [23].

However, both S. pneumoniae and K. pneumoniae were the highest bacteria isolated in HIV-negative patients; this might be due to the fact that both organisms are potential pathogens in the lower respiratory tract and they have been reported to cause pneumonia irrespective of the immune status. This is also agreed by [13].

Pneumonia in relation to gender in HIV/AIDS subjects revealed that male subjects are more predisposed to bacteria-associated pneumonia than female with $\mathrm{p}$ value 0.035 which is significant. This also agreed with the previous work of Kabra et al. (2010) who reported that pneumonia occurs more commonly in males than females, and more often in Blacks than Caucasians due to differences in synthesizing Vitamin D from sunlight. Although, the relationship between the bacteria isolated in relation to sex in HIV-negative patient is not statistically significant ( $P$ value 0.787). This might be due to the number of samples analyzed in HIV negative patient. 
Although, pneumonia is a major cause of death among all age groups [10]. Nevertheless, bacteria associated with pneumonia in HIV/AIDS patients in relation to age in this present study shows that age group 31-40 had the highest prevalence of bacteria-associated pneumonia. This might be due to the fact that this age group are active and can involve in various predisposing factor(s) identify by $[10,13]$. Age group 71-80 had the highest occurrence of pneumonia in HIV negative patients. This confirms that people with lower immune system, children and old age are more predisposed to bacteria-associated pneumonia [24].

Of all the twenty antibiotics tested in this present study, sparfloxacin was found out to be more effective against reasonable percentage of bacteria isolates in both studied populations, except $P$. aeruginosa isolates. Cotrimoxazole, a WHO recommended drug for the treatment of pneumonia was not effective against all the isolates except $20 \%$ of the K. pneumonia isolates. This also agreed with previous work of Adeleye et al. (2008) that reported Cotrimoxazole being strongly recommended by WHO as a primary or secondary prophylaxis for treatment of HIV bacterial infections in Africa was found to be resistant in Lagos, Nigeria.

Pseudomonas aeruginosa was found out to be resistant to all the 20 tested antibiotics. This could be due to efflux mechanism demonstrated by the organisms [28]. More so, self-medication being one of the factors identified by the patient has contributed immensely to the resistance pattern of the organisms. However, it has been documented that over the counter cough medicine has not been found helpful in pneumonia [26].

Staphylococcus aureus was resistant to some of the antibiotics used in this study. This might be due to the present of Panton-Valentine leukocidin virulence factor which had earlier been identify by Gadkowski and Stout (2008). The resistance of E. coli to some of the antibiotics was also recorded. This might be due to the mutations in the genes encoding ribosoma $\mathrm{Pl}$ protein and this has been reportedly associated with decreased permeability of the cell envelop in enteric bacteria by antibiotics, including plasmid- mediated mechanisms. Cross-resistance due to decrease permeability or other factors have been noted among antibiotics [11].

This study shows that the percentage of multiple resistances of isolates to nine classes of antibiotics tested from HIV/AIDS (53.0\%) is higher than that of HIV negative patients (19.2\%). This might be due to the fact that the patients engaged in self medication and multiple drug in-uses as identified by the questionnaire.

\section{Conclusion}

The multiple antibiotic resistances among bacterial isolates from various study groups are frightening because such organisms can become endemic within the environment and pose serious public health threats. However, this study has revealed findings concerning antimicrobial resistance among HIV/AIDS and HIV negative patients with bacteria pneumonia in the study population. It is also speculated that the widespread use of antibiotics may create pressure that encourages the selection of multi-drug resistance among bacteria [31].
Consequently, majority of the older antibiotics have been render ineffective. This is also seen in cotrimoxazole, a broad spectrum antibiotics, recommended by WHO for the treatment of pneumonia in Africa showed high degree of resistance to nearly all the bacteria isolates and as such sparfloxacin was found to be more effective in treatment of pneumonia in both HIV/AIDS and HIV negative patients. There is a need to carry out further work to detect what was responsible for antibiotics resistance among the bacteria isolates.

\section{Recommendation}

The problem of antibiotics resistance in bacterial pathogens typifies the growing concern among health care workers on the continued effectiveness of antibiotics in the empiric management of pneumonia infections. It is important to recall that antibiotic resistance profile in this study is to provide an updated data for clinicians, medical laboratory scientists and other heath care workers in order to facilitate the use of appropriate and more effective treatment regimes. However, in order to curb the problem of antibiotic resistance, indiscriminate use of antibiotics and over the counter sales of antibiotics should be discouraged and avoided. Above all, the search for alternative remedies concurrent with the quest for effective bacteria-pneumonia vaccines should be paramount. To this end, the use of antibiotics in treatment of bacteria associated pneumonia in this part of the world is very welcome. Therefore, sparfloxacin is highly recommended for the treatment of pneumonia both in HIV/AIDS and HIV negative patients. There is also need for continuous search for more effective antibiotics in different locations.

\section{Conflict of Interest}

There is no conflict of interest.

\section{References}

[1] Vray, M., Hecht, F.M. and Picker, L.J. (2008). Clinical features and etiology of pneumonia in acid-fast bacillus sputum smearnegative HIV-n infected patients hospitalized in Asia and Africa. AIDS 22: 1323-1332

[2] Jaspan, H.B., Huang, L.C., Cotton, M.F., Whitelaw, A. and Myer, L. (2008). Bacterial Disease and Antimicrobial Susceptibility Patterns in HIV-Infected, Hospitalized Children: A Retrospective Cohort Study. PLoS ONE 3(9): 3260.

[3] Bekele, A. and Bethany, G. (2009). Bacterial Pneumonia in Hospitalized Patients With HIV Infection. The Pulmonary Complications, ICU Support, and Prognostic Factors of Hospitalized Patients With HIV (PIP) Study.American Rev Respiratory Disease 148:1523-1529.

[4] Adeleye, A., Uju, L., Idika, N. and Sobande, O. (2008). Cotrimoxazole resistance in Streptococcus pneumoniae isolated from sputum of HIV-positive patients. West Indian medical Journal 57 no.5.

[5] Rano, A., Agusti, C., Sibila, O., Torres, A.(2005). Pulmonary infections in non-HIV-immunocompromised patients. Curr Opin Pulmonary Medical 11 (3): 213-217. WHO (2008). "Causes of death in neonates and children under five in the world 2004".

[6] Cordero, E. Pachón, J., Rivero, A., Girón-González, J., GómezMateos, M., Merino,M. Torres-Tortosa, M. González-Serrano, L. AND Collado, A. (2002). USEFULNESS OF SPUTUM CULTURE FOR DIAGNOSIS OF BACTERIAL PNEUMONIA 
IN HIV-INFECTED PATIENTS. European Journal of Clinical Microbiology and Infectious Diseases. Volume 21, number 5, 362367.

[7] Ochei, J. and Kolkhtar, A. (2000). Bacteriology: Medical Laboratory Science, theory and practice. In:Bulakh P.M. and Deshmukh S. (eds). Tata McGraw-Hill publishing Company limited New Delhi. Pp. 525-752.

[8] Cheesbrough, M. (2000). Microbiological test: District Laboratory Practice in Tropical Countries. In: Cremer, A. and Evan, G. (eds). Cambridge University Press, UK. Pp: 1-226.

[9] Clinical and Laboratory Standards institute (CLSI) (2010). Methods for the dilution, antimicrobial susceptibility test for bacteria. Approved standards. Ninth Editions (M09).

[10] Kabra, S.K., Lodha, R. and Pandey, R.M. (2010). "Antibiotics for community-acquired pneumonia in children". Cochrane Database System Reviews 3: Pp 1080-1090.

[11] Obi, C.L., Ramalivhana, J., Momba, M.N.B., Onabolu, B, Igumbor, J.O., Lukoto, M., Mulaudzi, T.B., Bessong, P.O., Jasen van Rensburg, E.L., Green, E. and Ndou, S. (2007). Antibiotics resistance profiles and relatedness of enteric bacterial pathogens isolated from HIV/AIDS Patients with or without diarrhoea and their household drinking water in rural communities in Limpopo Province South Africa. Africa Journal of Biotechnology. 6 (8):1035-1047.

[12] Anevlavis, S. and Bouros, D. (2010). "Community acquired bacterial pneumonia". Expert Opin Pharmacotherapy 11 (3): 36174.

[13] Gadkowski, L.B. and Stout, E. J. (2008). Cavitary Pulmonary Disease. Clinical Microbiology Reviews. 21, No. 2: 305-333.

[14] Idris, M and Nasidi, A (2009). The Pathophysiology and clinical manifestations of HIV/AIDS. Aids in Nigeria. 56: 245-356.

[15] Adeleye, A.I. (2010). Bacterial Bloodstream Infections in HIVinfected Adults Attending Lagos Teaching Hospital. Journal of Health, Population and Nutrition. 45 (13): 34-87.

[16] Falcó, V., Fernández de Sevilla, T., Alegre, J., Barbé, J., Ferrer, A., Ocaña, I., Ribera, E., Martínez-Vázquez, J.M. (1994). Bacterial pneumonia in HIV-infected patients: a prospective study of 68 episodes. J. European Respiratory, 7, 235-239.

[17] Franzetti, F., Cernuschi, M., Esposito, R., Moroni, M. (1992). Pseudomonas infection in patients with AIDS and AIDS related complex. Journal of Internal Medicine; 231: 437-443.

[18] Franzetti, F., Grassini, A., Piazza, M., Degl'Innocenti, M., Bandera, A., Gazzola, L.,Marchetti, G. and Gor, A. (2007). Nosocomial Bacterial Pneumonia in HIV-Infected Patients: Risk Factors for Adverse Outcome and Implications for Rational Empiric Antibiotic Therapy Journal of Infection. Volume 34, Number 1, 9-16.
[19] Okesola, A.O. and Oni, A.A. (2009). Antimicrobial resistance among common bacteria pathogens in South West, Nigeria. American Journal Agricultural environmental Science. 5(3): 327330.

[20] Wang, F., Zhu, D.M., Hu,P.P. and Zhang, Y.Y.(2001). Surveilance of bacterial resistance among isolates in Shanghai in 1999. Journal of infection chemotherapy. 7(2): 117-120.

[21] El kholy, A.Basseem, H., Hall, G.S, Procop, G.W. and Lorngworth, D.L. (2003). Antimicrobial resistance in Cairo, Egypt, 1999-2000: a survey of five hospitals. Journal antimicrobial chemotherapy 51(3): 625-630.

[22] Turner, D. and Dagan, R. (2001). The sensitivity of common bacteria to antibiotics in children in South Isreal, Harefuah. Amerian Journal of Epidemiology. 140(10): 923-929. eMedicine Dictionary, 2008. pneumonia. Pp. 2205-2230.

[23] Oluyege, A.O., Dada, A.C., Ojo, A.M. and Oluwadare, E. (2009). Antibiotics resistance profile of bacterial isolates from food sold on University campuses in South West, Nigeria. Journal of Biotechnology. 8 (21) 5883-5887.

[24] Ashby, B. and Turkington, C. (2007). The encyclopedia of infectious diseases (3 Ed.). New York: Facts on File. p. 242.

[25] Jawertz, E, Melnick, J. and Adelberg, E.A. (2007). Hepatitis Viruses. In: Medical Microbiology. Brooks G.F, Butel J.S., Morse S.A. $22^{\text {nd }}$ ed(s) Lange medical books/Mc Graw-Hill Medical publishing Division, New York. Pp 403-417.

[26] Chang, C.C., Cheng, A.C. and Chang, A.B. (2007). "Over-thecounter (OTC) medications to reduce cough as an adjunct to antibiotics for acute pneumonia in children and adults". Cochrane Database System Rev (4): CD006088.

[27] Isenberger, K. Hill, D.W., Jenkins, L.E. and Magee J.T. (2002). Clinical significance of the emergence of bacterial resistance in the hospital environment. Journal of Applied Microbiolog. 92: 908-978.

[28] Lipps, G. (2008). Plasmid. Current Research and future trends. Caister Academic Press.

[29] Kroll, J. Klinter, S., Schneider, C. and Steinbuchel, A. (2010). Plasmid addition systems: Perspective and application in biotechnology microbiology. Journal of Biotechnology. 3(6): 634657.

[30] Krause, D.C. and Balish, M.F. (2004). "Cellular engineering in a minimal microbe: structure and assembly of the terminal organelle of Mycoplasma pneumoniae". Molecular Microbiology 51 (4): 917-24.

[31] Pratts, G., Mirelis, B. And Llovelt, T. (2000). Antibiotics resistance trends in enteropathogenic bacteria isolated in 19851987 and 1995-1998 in Barcelona. Antimicrobial agents chemotherapy. $44: 1140-1145$. 